\title{
Differential susceptibility of HIV strains to innate immune factors in human cervical-vaginal secretions
}

This article was published in the following Dove Press journal:

Virus Adaptation and Treatment

I July 2010

Number of times this article has been viewed

\author{
Mimi Ghosh \\ John V Fahey \\ Charles R Wira \\ Department of Physiology \\ and Neurobiology, Dartmouth \\ Medical School, Lebanon, \\ New Hampshire, USA
}

Correspondence: Charles R Wira Department of Physiology, Dartmouth Medical School, One Medical Center Drive, Lebanon, NH 03756, USA

$\mathrm{Tel}+\mathrm{I} 603650-7733$

Fax + I 603 650-6I30

Email charles.r.wira@dartmouth.edu

\begin{abstract}
The female reproductive tract (FRT) is protected by innate and adaptive immune mechanisms, which work in concert to defend against human immunodeficiency virus (HIV) and other sexually transmitted infections (STIs). Under the control of sex hormones throughout a woman's life, the immune system in the FRT has evolved to meet the challenges of protection against STIs, coupled with the need to sustain the development of new life. The studies presented in this review focus on the threat of HIV infection and the levels of protection present in the FRT during the menstrual cycle. Studies from our laboratory and others, examined the presence and variability of immune components against viral infection in the FRT. Our findings indicate that there are some factors in the FRT secretions that inhibit and enhance infectivity of individual strains of HIV. Given the complexities of hormonal regulation, identification of the elements involved in susceptibility to and protection against HIV in women must involve a careful analysis of transmitted viruses and a clear understanding of immune protection in the FRT.
\end{abstract}

Keywords: HIV susceptibility, CVL

\section{HIV and the human female reproductive tract}

With 25 million deaths and an additional 33.4 million people (of which approximately $50 \%$ are female) currently infected worldwide, human immunodeficiency virus/acquired immunodeficiency syndrome (HIV/AIDS) has become one of the world's worst pandemics (UNAIDS 2009 Global Report). ${ }^{1}$ More than $80 \%$ of the new HIV infections are acquired through heterosexual transmission, ${ }^{1}$ and women are more likely than men to be infected in heterosexual intercourse. ${ }^{2}$ Despite these findings, the rate of HIV transmission in women per coital act remains strikingly low at 1:122-1:1,000. ${ }^{3-5}$ We and others have reached the conclusion that in addition to viral load, ${ }^{6}$ exposure time following seroconversion, ${ }^{7}$ and preexistence of other sexually transmitted infections (STIs), ${ }^{8-10}$ the immune protection in the human female reproductive tract (FRT) influences the transmission of HIV. ${ }^{11}$

The lower FRT (cervix and vagina) is generally considered a primary site of HIV-1 infection, but recent observations suggest that the upper FRT (uterus and fallopian tube) might also be a portal for the entry of HIV-1 following sexual intercourse. Depending on the site analyzed, factors that play a role in inhibiting or enhancing infectivity include coinfections, microabrasions, secreted immune factors, genetics, and menstrual status, all of which affect the local immune system. In addition, disease state and local viral load of the donor are very important determinants. ${ }^{12}$ Genetic, behavioral, and economic risk factors also play a major role in determining susceptibility to HIV. 


\section{HIV laboratory strains and transmitted viruses}

To completely understand how the HIV infects, researchers have taken advantage of the available viral isolates, some of which were adapted to grow in cell culture. These HIV strains, as well as clinical isolates, are often characterized by their preferential attachment to the target cells that express CXCR4 chemokine coreceptors (X4), CCR5 chemokine coreceptors (R5), or both (X4/R5). Only recently has HIV research undergone a paradigm shift. By investigating HIV patients early after infection, Hahn, Shaw, and colleagues used single genome amplification to identify transmitted/ founder viruses that were responsible for heterosexual infection. ${ }^{13}$ It is generally accepted that the donor seminal fluid contains multiple HIV variants, among which only the macrophage-tropic/R5 viruses cause infection. This was thought to be due to T-cell-tropic/X4 virus recognition and inhibition by mucosal epithelial cells (ECs), which is evaded by R5 viruses, which pass through the ECs via transcytosis without getting detected. ${ }^{14}$ Hahn and Shaw's studies led to the concept of a bottleneck for the sexual transmission of HIV, through which a single variant of R5 transmitted/ founder virus traverses the mucosal barrier to infect women. ${ }^{15}$ Current studies are directed toward understanding the nature of these transmitted or founder viruses as to what makes them successful in invading the host.

\section{The mucosal immune system of the FRT: layers of protection against HIV infection}

The mucosal immune system in the FRT contains an array of protective mechanisms that extends through both the upper and the lower tracts. The immune protection is provided by both the innate and the adaptive immune systems. These systems consist of resident ECs, supportive stromal cells, and immune cells, which migrate into the uterus, cervix, and vagina. Among those cells pivotal in conferring immune protection, ECs are found to be pluripotential with abilities to confer protection against HIV. ECs, in addition to providing barrier protection, transport immunoglobulins (IgA and $\operatorname{IgG}$ ) into FRT secretions and produce antimicrobials that are both bactericidal and viricidal. ${ }^{16,17}$ Through the production of cytokines and chemokines, these cells signal the recruitment and activation of other cells of the innate and adaptive immune systems that are resident throughout the FRT. Our goal in the following sections is to highlight some of the abilities of these epithelial and immune cells in the FRT in protecting against HIV and to point out that all these cells are responsive to sex hormones. In the second part of this review, special emphasis will be placed on HIV and our evolving understanding of the role of the FRT in protecting against viral infection via the FRT.

\section{Barrier and $\mathrm{pH}$ protection}

As the first cells to make contact with the pathogens, the columnar ECs of the endocervix, uterus, and fallopian tubes are polarized and form tight junctions that physically prevent pathogens from entering the body. In contrast, squamous ECs lining the lower tract (vagina and ectocervix) do not form tight junctions, but have multiple layers of cornified cells that retard pathogen penetration. In addition tight junctions, pathogens encountering the lower tract are exposed to an acidic $\mathrm{pH}$ that is maintained by commensal bacteria in healthy women. The envelope glycoprotein (gp120) of HIV is particularly sensitive to an acidic environment. ${ }^{18,19}$ Interestingly, gp120 of certain strains of HIV are more sensitive to acidic $\mathrm{pH}$ than other strains, which might allow some strains to survive and infect better than others. ${ }^{18,20}$ The loss of vaginal acidity and/or commensals is known to make women more susceptible to pathogens. ${ }^{21}$ Mucus overlaying the EC in the FRT also can trap HIV and prevent infection of underlying target cells or transcytosis through an epithelial layer. ${ }^{22}$

\section{Protection provided by secreted immune factors}

Another level of protection is provided by the innate immune system that secretes cytokines, chemokines, and antimicrobials both constitutively and in response to pathogenic challenge. To respond to pathogens, immune cells in the upper and lower FRT express functional pathogen-recognition receptors including toll-like receptors, NOD-like receptors, and RIG-like helicases (RIG-1 and MDA5) ${ }^{23-27}$ (Ghosh et al unpublished results). The response to pathogens is mediated through the secretion of antimicrobials, cytokines, and chemokines. Several antimicrobial molecules have been reported in FRT secretions, which include $\alpha$ and $\beta$ defensins, secretory leukocyte protease inhibitor (SLPI), elafin, and LL37, all of which inhibit HIV. ${ }^{27-32}$ Some factors such as MIP3 $\alpha$ function as a dual mediator that has both antibacterial and antiviral activities, as well as chemokine activity, which attracts $\mathrm{T}$ cells and immature dendritic cells (DCs) to the site of pathogenic invasion. ${ }^{33,34}$ Secreted immune factors can therefore act as recruiters or activators of other cells, some of which are targets for HIV infection. 


\section{Intracellular antiviral activity}

In addition to the protection provided by the secreted immune factors, there exists a well-developed system of intracellular antiviral protection within the FRT. Within ECs and macrophages, for example, intracellular protection is interferon mediated. Upon viral infection, the interferons upregulate genes such as MxA, 2,5-oligoadenylate synthetase (OAS), and RNA-activated protein kinase (PKR). As discussed in previous studies, these genes belong to a large family of interferon-stimulated genes that inhibit multiple viruses at various stages of their life cycle. ${ }^{35-39}$ Some studies indicate that HIV-1 uses immune escape mechanisms to evade these intracellular antivirals, suggesting that these pathways are important for preventing successful infection by HIV. ${ }^{40}$

\section{Innate immune cells}

Innate immune cells involved in FRT immune responses include the DC, macrophages, natural killer (NK) cells, and neutrophils. Found throughout the FRT, ${ }^{41}$ these cells are phenotypically and functionally distinct from their counterparts in the peripheral circulation and/or tissues. ${ }^{16,42,43}$ For example, cell-cell interactions in tissue microenvironments determine if the DCs adopt immunogenic or tolerogenic features. We recently found that the secretions of uterine ECs lower the DC expression of CD80 and CD86, reduce immunogenic cytokine secretion, enhance IDO expression, and decrease DC capability to induce allogeneic T-cell proliferation, all characteristic of tolerogenic DC. ${ }^{44}$ Tolerogenic DCs may be critical for optimal reproductive function of the uterus and for the sustained presence of DCs in the uterus. Uterine macrophages are distinct from most monocyte-derived tissue macrophages. Circulating monocytes migrate into tissues and differentiate into macrophages that can participate in responses to pathogens by secreting proinflammatory effectors, such as interleukin-1 $\beta$ (IL-1 $\beta$ ). However, monocyte-derived macrophages, as well as intestinal and alveolar macrophages, are deficient in their ability to release mature, active IL- $1 \beta$ in response to lipopolysaccharide stimulation. Inefficient processing of precursor IL-1 $\beta$ by these cells is due to the lack of caspase-1 (IL- $1 \beta$-converting enzyme) activity. In contrast to other macrophages, uterine macrophages have caspase- 1 activity, which enable the secretion of mature IL-1 $\beta$ that facilitates implantation and mediates protection from pathogens ${ }^{45}$ Thus, primary uterine macrophages are unique among other tissue macrophages. NK cells are known to "kill" tumor cells and secrete cytokines that link the innate and adaptive immune systems. Uterine NK cells have a unique phenotype compared with blood NK cell subsets. ${ }^{46}$ For example, NK cells in the fallopian tubes, endometrium, cervix, and ectocervix are CD56+bright and express CD9, while blood NK cells are CD56+dim and do not express CD $9{ }^{47}$ Alterations in the physiological levels of NK cells in the FRT have been linked to a number of clinical conditions leading to reproductive failure. ${ }^{48} \mathrm{We}$ have demonstrated that NK cells are present in various FRT tissues and that their phenotypes and regulation largely depend on the FRT tissue where they reside. ${ }^{47}$ Furthermore, the number of NK cells varies with the menstrual cycle in the endometrium, but not in the cervix or ectocervix. Recently, using Affymetrix microarrays with probes representing approximately 47,400 transcripts, we showed that human decidual NK cells from gravid uteri and NK cells from cycling endometrium are distinct NK cell subsets. ${ }^{49}$ These data suggest that a unique local environment in FRT tissues may account for the recruitment of different NK cell subsets. We also compared neutrophils derived from fallopian tubes with neutrophils isolated from peripheral blood. Fallopian tube neutrophils express significantly higher levels of CD64, human class II histocompatibility antigen DR, gamma-interferon, and vascular endothelial growth factor than those from peripheral blood ${ }^{43}$ Fewer fallopian tube neutrophils expressed IL-8 receptors compared with blood neutrophils, while more express the receptor for the bacterial-derived chemoattractant formyl-Met-Leu-Phe. The number of fallopian tube neutrophils containing the granule proteins matrix metalloproteinase-9, lactoferrin, and myeloperoxidase decreased relative to those in blood. Thus, macrophages, NK cells, and neutrophils exhibit a phenotype distinct from their blood counterparts, suggesting functional activation of innate immune defense that is unique to the FRT. Each of these cells in the FRT contributes to protection against pathogens, including HIV. As professional antigen-presenting cells in the FRT, macrophages and DCs capture HIV prior to their transfer to the T cells. ${ }^{50}$ Macrophages secrete a number of chemokines, such as MIP- $1 \alpha$ and MIP-1 $\beta$ that block HIV from binding to HIV coreceptors. NK cells along with neutrophils are known to secrete antimicrobials that inhibit HIV and other pathogens that threaten reproductive tract homeostasis.

\section{Adaptive immune cells}

The adaptive immune system has evolved to elicit specific defense mechanisms. An effective immune response to pathogens requires that the antigen-presenting cells process the antigen from a pathogen and present it to the $\mathrm{T}$ cells, thereby inducing T-cell activation. Following antigen 
presentation, lymphocyte effector functions, including cytokine production, cytotoxicity, and antibody synthesis, are activated. Protection is mediated through antibodies produced by B cells (humoral immunity) or the destruction of specific pathogens directly or indirectly by $\mathrm{T}$ cells (cell-mediated immunity). The cell surface proteins are identified on $\mathrm{T}$ cells and are used routinely to identify all T cells (CD3) or T-cell subgroups that help either in the production of antibodies (CD4) or in the killing of infected cells (CD8). CD4 ${ }^{+} \mathrm{T}$ cells are believed to be the first cells to be infected in the FRT upon sexual transmission. ${ }^{51}$ With regard to HIV exposure, pathogen-specific antibodies (IgG and $\operatorname{IgA}$ ) and cytotoxic $\mathrm{T}$ lymphocytes have been identified to play a major role in the protection of the FRT mucosa..$^{52,53}$

\section{Hormonal regulation of innate and adaptive immune responses}

It is not widely recognized that all the aspects of immune protection in the FRT discussed earlier are under hormonal influence. ${ }^{11,16}$ Control of local mucosal immune function by sex hormones, estradiol and progesterone, is precisely regulated to ensure successful fertilization and pregnancy, at the same time conferring protection against STIs, which threaten to compromise women's reproductive health and survival. Based on our previous studies and those of others, we found a pattern of local immune suppression of some but not all aspects of the immune system. These findings led us to propose the existence of a window of vulnerability extending to both the upper and the lower FRT, which, although essential for successful reproduction, makes women more vulnerable to infections during the middle of the menstrual cycle (days 14-21), when the reproductive tract is prepared to accept an immunologically distinct conceptus or fetus. ${ }^{11,54}$ Under these circumstances, HIV and other STIs may take advantage of this temporary modified "tolerogenic" environment to infect cells and cause illness. ${ }^{11}$

\section{Anti-HIV immune factors in cervical vaginal lavages and differential susceptibility of HIV strains}

A valuable and noninvasive tool, used in our laboratory, for studying immune responses in the FRT is the collection of cervical vaginal lavages (CVLs) that can then be used for a number of different assays. In our studies, the cervical vaginal area was rinsed with $10 \mathrm{~mL}$ of $\mathrm{pH}$-neutral saline prior to the collection of CVL samples. Later, the samples were centrifuged for the recovery of fluid and cellular components. The supernatants were collected from both HIV(-) women (healthy) and HIV(+) women (healthy, not on antiretrovirals) and were used to determine the extent to which they neutralize HIV-1 infection of a TZM-bl indicator cell line. We used 4 reference viruses (X4: IIIB, NL4.3, R5: BaL, and YU-2c) and the $\mathrm{R} 5$ transmitted/founder virus $\mathrm{CH}$ 077.c. As shown in the upper portion of Table 1, CVL from some healthy HIV $(+)$ patients (A, B, C) had broad-spectrum inhibitory activity against all HIV strains tested, including the transmitted virus. Unexpectedly, we also found a tremendous variability in the neutralizing capacity of a given CVL sample toward different strains of HIV. For example, some healthy HIV(+) CVL samples were found to be highly inhibitory against one HIV-1 strain, whereas the same CVL failed to inhibit another strain (Table 1: D-F). Moreover, we found a few CVL (Table 1: G-I) from the same cohort that enhanced infection of several HIV strains, including the transmitted virus (Table 1).

When we compared the mean percent inhibition between the HIV $(+)$ and HIV(-) groups, the results differed depending on the viral strain tested. IIIB (X4), NL4.3 (X4), and BaL (R5) were similarly inhibited by CVL from $\operatorname{HIV}(+)$ and $\operatorname{HIV}(-)$ individuals. In contrast, activity against YU-2.c (R5) and CH077 (R5, transmitted/founder) was significantly higher in HIV(-) CVL than in HIV(+) CVL (data not shown). Given the number of immune factors present in the CVL, ${ }^{54}$ our data suggest that different factors have differential activity against the strain of HIV tested. Specifically, in our study, we measured protein concentrations of HBD2, MIP3 $\alpha$, SLPI, and elafin in the HIV(+) CVL and found

Table I CVL that enhanced infection of several HIV strains

\begin{tabular}{|c|c|c|c|c|c|c|}
\hline & \multirow[t]{2}{*}{$\begin{array}{l}\text { Patient } \\
\text { no. }\end{array}$} & \multicolumn{2}{|c|}{$\begin{array}{l}\text { X4 } \\
\text { (\% inhibition) }\end{array}$} & \multicolumn{2}{|c|}{$\begin{array}{l}\text { R5 } \\
\text { (\% inhibition) }\end{array}$} & \multirow[b]{2}{*}{ CH077.c } \\
\hline & & IIIB & NL4.3 & $\mathrm{BaL}$ & YU-2.c & \\
\hline \multicolumn{7}{|c|}{ CVL with broad inhibitory activity } \\
\hline & $\mathrm{A}$ & 100 & 100 & 98 & 82 & 78 \\
\hline & B & 100 & 99 & 90 & 91 & 96 \\
\hline & C & 95 & 100 & 86 & 92 & 96 \\
\hline Mean & & 98 & 100 & 91 & 88 & 90 \\
\hline SEM & & 2 & 0 & 4 & 3 & 6 \\
\hline \multicolumn{7}{|c|}{ CVL with variable inhibitory activity } \\
\hline & $\mathrm{D}$ & 63 & 46 & 14 & 0 & 36 \\
\hline & $E$ & 79 & 0 & 15 & 65 & 41 \\
\hline & $\mathrm{F}$ & 0 & 69 & -32 & 82 & 63 \\
\hline Mean & & 47 & 38 & -1 & 49 & 47 \\
\hline SEM & & 24 & 20 & 16 & 25 & 8 \\
\hline \multicolumn{7}{|c|}{ CVL with enhancing activity } \\
\hline & G & -60 & -46 & -58 & -86 & -43 \\
\hline & $\mathrm{H}$ & II & -20 & 14 & -45 & -6 \\
\hline & I & -61 & 29 & -65 & 25 & -31 \\
\hline Mean & & -37 & -12 & -36 & -35 & -27 \\
\hline SEM & & 24 & 22 & 25 & 32 & II \\
\hline
\end{tabular}


that MIP $3 \alpha$ levels correlated with anti-HIV activity against all 3 R5 viruses, but not the X4 viruses. However, HBD2 concentrations were correlated with IIIB and $\mathrm{BaL}$, but not YU-2c, NL4.3, and CH077 (data not shown; Ghosh et al unpublished results).

Some of the known anti-HIV factors present in CVL are SLPI and defensins. ${ }^{55-57}$ Previous studies have shown that these factors can operate through multiple mechanisms. SLPI can block HIV fusion and entry by interacting with cell surface phospholipid-binding proteins annexin II and phospholipid scramblase 1 and $4 .{ }^{58,59} \mathrm{HBD} 2$ and HBD3 have been shown to inhibit HIV infection through direct interaction, modulation of CXCR 4 coreceptor, ${ }^{60}$ and post - reverse transcription mechanisms. ${ }^{61}$ In contrast, alpha defensins inhibit HIV infection by interfering with the binding of envelope protein gp120 to the CD4 receptor. ${ }^{62} \mathrm{HBD} 2$ and HBD3 have been shown to inhibit X4 HIV more efficiently compared with R5 strains of HIV. ${ }^{60}$ SLPI is known to inhibit both X4 and R5 strains of HIV with reduced inhibitory capacity toward strains with broad coreceptor usage. ${ }^{63}$ Data from our laboratory, however, indicate that HIV inhibition by factors in the CVL is likely to be more complex than viral tropism. The 12-20 innate immune mediators present in the FRT secretions vary with the stage of the menstrual cycle. ${ }^{11,54}$ For example, King et $\mathrm{al}^{30}$ have shown that in the human endometrium, HBD1, HBD3, and SLPI are maximally expressed during the secretory phase; HBD4 is expressed highest during the proliferative phase; whereas HBD2 and elafin expressions peak during menstruation. This might explain the kind of variability in inhibition that we observed in our samples. The studies in progress in our laboratory are designed to identify the factor(s) in CVL from healthy women responsible for anti-HIV activity at different stages of the menstrual cycle.

Another explanation for the differential susceptibility observed among HIV strains in our study might be due to the differences in biological activity of anti-HIV molecules found in CVL. Many of these molecules are expressed as precursor proteins that must be cleaved for activation and/or release in secretions. Both defensins and elafin fall into this category. HD5 cleavage by trypsin is essential for both chemotactic and antimicrobial functions. ${ }^{64}$ Elafin is expressed as trappin-2, attached to the cell surface. Upon activation by tryptase, it is released as elafin into the secretions. ${ }^{65}$ In this case, both the cell-surface-attached and the secreted forms are antimicrobial. Multiple families of proteases are abundant in the secretions of the reproductive tract and are specific in their actions to activate and deactivate immune factors. The cathepsin family of proteases is such an example. The cathepsins regulate the family of matrix metalloproteases, which are themselves responsible for activating and deactivating innate immune factors including the anti-HIV molecules CXCL12 and HNP1. ${ }^{66-69}$ Cathepsins are also responsible for directly regulating anti-HIV innate immune factors. ${ }^{70-72}$ For example, cathepsin $\mathrm{D}$, a cysteine protease present in vaginal secretions, ${ }^{73}$ has been shown to enhance HIV replication. ${ }^{74,75}$ Although the mechanisms are unclear, it is known that cathepsin D inhibits MIP $3 \alpha,{ }^{70}$ a known anti-HIV factor in CVL. ${ }^{34}$ Kallikreins (KLKs) are another family of serine proteases present in the genital mucosa that can activate/deactivate multiple immune factors in the FRT. ${ }^{76,77}$ For example, KLK5 has been shown to regulate the antimicrobial activity of LL37, a potent anti-HIV molecule. ${ }^{78,79}$ CD26/dipeptidyl peptidase IV is a serine protease responsible for the cleavage and inactivation of chemokines, such as regulated on activation, normal T cell expressed and secreted (RANTES) and stromal cell-derived factor-1 (SDF1), which are involved in blocking HIV entry. ${ }^{80,81}$ As discussed previously, many of these chemokines, including MIP $3 \alpha$, MIP1 $\alpha$, MIP1 $\beta$, RANTES, and SDF1, are antimicrobials with anti-HIV activity. ${ }^{34,82,83}$ Another level of complexity, beyond their ability to activate and inactivate FRT antimicrobials is that these protease families are regulated throughout the menstrual cycle by protease inhibitors present in the secretions. Several protease inhibitors, such as SLPI and elafin, are also known anti-HIV molecules. ${ }^{84-86}$ Overall, these findings indicate the several levels of complexity present in the FRT that have to be addressed as we identified the molecules in CVL responsible for anti-HIV immune protection.

Although hormone regulation plays a key role in the immune response to HIV (and other STI) infection of the FRT, it is as yet unclear whether estradiol and progesterone directly affect HIV replication/infection. Some studies have shown that estradiol can bind to the estrogen response element located within the HIV long terminal repeat and can enhance viral transcription directly. ${ }^{87,88}$ However, whether this takes place in vivo is unclear. Several studies have shown correlations between women taking oral contraceptives (OC) and an increased risk of seroconversion; ${ }^{89-91}$ however, others have failed to find any correlation. ${ }^{92,93}$ Higher progesterone levels, such as in pregnancy and OC usage, which change the commensal flora in the vagina, are believed to be risk factors for acquiring HIV. ${ }^{94}$ In macaque studies, progesterone treatment increased viral acquisition, presumably through thinning of the vaginal epithelium that develops with OC usage. ${ }^{95}$ This same study also found protective effects 
of estrogen in terms of HIV acquisition. A recent study has shown that high progesterone, as found in pregnancy, can enhance the expression of CCR5 (HIV coreceptor for the sexually transmitted R5 HIV strains) on $\mathrm{CD}_{14}{ }^{+}$and $\mathrm{CD}^{+}$ HIV target cells in both peripheral blood mononuclear cells and vaginal biopsy samples. ${ }^{96}$

\section{Enhancement of HIV infection by immune factors in CVL}

In our studies (Table 1), several CVL samples (20\%) were found to contain factors that enhanced HIV-1 infection of TZM-bl cells. Enhancement of HIV infection of target cells in the presence of mucosal fluids has been described previously. ${ }^{97-100}$ Several studies have found a correlation of plasma viral load (PVL), as well as genital tract viral load (GTVL), with enhanced viral infection of target cells. ${ }^{101,102}$ Other studies, however, have shown that the presence of infectious virus in CVL is not related to the viral load in periphery or genital tract as measured typically by polymerase chain reaction (PCR). ${ }^{103}$ In our studies (Ghosh et al unpublished results), we found that out of $57 \mathrm{HIV}(+)$ women with both high and low PVL and GTVL measured by PCR, only 3 were capable of infecting TZM-bl cells. There were no correlations among viral load and the ability to infect TZM-bl cells in these 3 samples, although all had existing coinfections (2, BV; 1 , Trichomonas). These data suggest that in vivo GTVL might not correlate with the shedding of infectious virus, which would be the primary determining factor in sexual transmission. This observation confirms the findings of others. ${ }^{104,105}$

Bacterial and viral coinfections are important cofactors for HIV transmission and infection. Bacterial vaginosis is the most well-described cofactor that has been shown to enhance HIV replication. ${ }^{106,107}$ Infection by herpes simplex virus, Chlamydia, and other sexually transmitted pathogens has also been described to play a role in enhancing HIV infection and transmission. ${ }^{8,9}$ It is generally accepted that coinfecting pathogens result in a localized immune response and environment that favors HIV replication. ${ }^{10,106}$ Specific factors known to directly stimulate viral replication include proinflammatory cytokines, such as IL-6, tumor necrosis factor- $\alpha$, and IL $1 \beta^{108-111}$ Other mucosal innate immune factors that have been reported to have an enhancing effect on viral replication include mucosal factor MRP8 ${ }^{98,112}$ and scavenger receptor gp340. ${ }^{100}$ Similarly, Levinson et $\mathrm{al}^{113}$ and Kaul et $\mathrm{al}^{9}$ demonstrated that the presence of anti-HIV molecules, such as RANTES and defensins, in genital secretions can enhance viral replication by attracting target cells that can be infected by HIV. Cathepsin D has been shown to enhance
HIV replication ${ }^{74,75}$ possibly through inhibition of MIP3 $\alpha$, a known anti-HIV factor present in CVL. ${ }^{34}$ It is also known that cathepsin D and its receptor are regulated by estradiol. ${ }^{114}$

Overall, the challenge in determining the exact mechanisms by which HIV infection is inhibited or enhanced in a given CVL sample lies in the sheer number of innate immune factors and their regulators present in CVL and the extent to which they are present throughout the menstrual cycle. The closest to come in examining these complexities was a study undertaken to deplete all cationic components of CVL (given that several of the innate anti-HIV factors are cationic in nature). ${ }^{115}$ Although depletion of cations resulted in the loss of anti-HIV activity, the complexities of hormonal effects were not taken into account. The fact that many of these factors affect HIV strains in a differential manner further emphasizes the need for a thorough examination of the antimicrobials present, their biological activities, and relative contribution to anti-HIV activity under various endocrine conditions.

\section{Conclusion}

Our goal in this review was to examine the spectrum of innate factors in the FRT that most likely contributes to the differential susceptibility to infection of target cells with HIV-1 strains. The FRT is a complex tissue with fine-tuned mechanisms of immune regulation that optimize conditions for fertilization and pregnancy, while providing protection against pathogens. Although the HIV pandemic continues to expand with women being affected disproportionately, we have yet to fully understand what makes a woman more or less susceptible to HIV infection. With the flurry of recent publications on transmitted/founder viruses, there is intensive interest in identifying the unique properties of these viruses that enable infection through the genital mucosa. Our findings presented in this review indicate that there are factors in the FRT secretions that differentially affect individual strains of HIV. Given the complexity of hormonal regulation of these factors and their regulators in CVL, identification of the elements involved in enhanced susceptibility of women to specific strains of HIV will involve both careful analysis of transmitted viruses and a clear understanding of immune protection in the FRT. Our findings suggest that the identification of biologically active anti-HIV immune molecules of the FRT during the different stages of the menstrual cycle will be instrumental in advancing our understanding of sexual transmission of HIV in women and will offer avenues not previously considered for preventing the sexual transmission of HIV. 


\section{Disclosure}

The authors report no conflicts of interest in this work.

\section{References}

1. UNAIDS 2009 Global Report; 2009. Available from: http://www. unaids.org/en/.

2. CDC. HIV/AIDS surveillance Report. AUDoHaHS. CDC. 2003; 2003.

3. Gray RH, Wawer MJ, Brookmeyer R, et al. Probability of HIV-1 transmission per coital act in monogamous, heterosexual, HIV-1-discordant couples in Rakai, Uganda. Lancet. 2001;357(9263):1149-1153.

4. Ndesendo VM, Pillay V, Choonara YE, et al. A review of current intravaginal drug delivery approaches employed for the prophylaxis of HIV/AIDS and prevention of sexually transmitted infections. AAPS Pharm Sci Tech. 2008;9(2):505-520.

5. Wawer MJ, Gray RH, Sewankambo NK, et al. Rates of HIV-1 transmission per coital act, by stage of HIV-1 infection, in Rakai, Uganda. J Infect Dis. 2005;191(9):1403-1409.

6. Quinn TC, Wawer MJ, Sewankambo N, et al; Rakai Project Study Group. Viral load and heterosexual transmission of human immunodeficiency virus type 1. N Engl J Med. 2000;342(13):921-929.

7. Colfax GN, Buchbinder SP, Cornelisse PG, et al. Sexual risk behaviors and implications for secondary HIV transmission during and after HIV seroconversion. AIDS. 2002;16(11):1529-1535.

8. Corey L, Wald A, Celum CL, Quinn TC. The effects of herpes simplex virus-2 on HIV-1 acquisition and transmission: a review of two overlapping epidemics. JAcquir Immune Defic Syndr. 2004;35(5): 435-445.

9. Kaul R, Pettengell C, Sheth PM, et al. The genital tract immune milieu: an important determinant of HIV susceptibility and secondary transmission. J Reprod Immunol. 2008;77(1):32-40.

10. Wald A, Link K. Risk of human immunodeficiency virus infection in herpes simplex virus type 2-seropositive persons: a meta-analysis. $J$ Infect Dis. 2002;185(1):45-52.

11. Wira CR, Fahey JV. A new strategy to understand how HIV infects women: identification of a window of vulnerability during the menstrual cycle. AIDS. 2008;22(15):1909-1917.

12. Chakraborty H, Sen PK, Helms RW, et al. Viral burden in genital secretions determines male-to-female sexual transmission of HIV-1: a probabilistic empiric model. AIDS. 2001;15(5):621-627.

13. Keele BF, Giorgi EE, Salazar-Gonzalez JF, et al. Identification and characterization of transmitted and early founder virus envelopes in primary HIV-1 infection. Proc Natl Acad Sci U S A. 2008;105(21): 7552-7557.

14. Asin SN, Fanger MW, Wildt-Perinic D, et al. Transmission of HIV-1 by primary human uterine epithelial cells and stromal fibroblasts. J Infect Dis. 2004;190(2):236-245.

15. Haaland RE, Hawkins PA, Salazar-Gonzalez J, et al. Inflammatory genital infections mitigate a severe genetic bottleneck in heterosexual transmission of subtype A and C HIV-1. PLoS Pathog. 2009;5(1): e1000274.

16. Wira CR, Fahey JV, Sentman CL, Pioli PA, Shen L. Innate and adaptive immunity in female genital tract: cellular responses and interactions. Immunol Rev. 2005;206:306-335.

17. Kaushic C, Wira CR. IgA and reproductive tract immunity. In: Kaetzel C, editor. IgA and Reproductive Tract Immunity. New York: Kluwer Academic/Plenum; 2008:291-320.

18. Fletcher PS, Harman SJ, Boothe AR, Doncel GF, Shattock RJ Preclinical evaluation of lime juice as a topical microbicide candidate. Retrovirology. 2008;5:3.

19. Ongradi J, Ceccherini-Nelli L, Pistello M, Specter S, Bendinelli M. Acid sensitivity of cell-free and cell-associated HIV-1: clinical implications. AIDS Res Hum Retroviruses. 1990;6(12):1433-1436.

20. Connor RI. Sensitivity of non-clade B primary HIV-1 isolates to mildly acidic pH. J Acquir Immune Defic Syndr. 2006;43(4):499-501.
21. Spear GT, Zariffard MR, Cohen MH, Sha BE. Vaginal IL-8 levels are positively associated with Candida albicans and inversely with lactobacilli in HIV-infected women. $J$ Reprod Immunol. 2008;78(1): 76-79.

22. Maher D, Wu X, Schacker T, Horbul J, Southern P. HIV binding, penetration, and primary infection in human cervicovaginal tissue. Proc Natl Acad Sci U S A. 2005;102(32):11504-11509.

23. Aflatoonian R, Fazeli A. Toll-like receptors in female reproductive tract and their menstrual cycle dependent expression. $J$ Reprod Immunol. 2008;77(1):7-13.

24. Fazeli A, Bruce C, Anumba DO. Characterization of Toll-like receptors in the female reproductive tract in humans. Hum Reprod. 2005;20(5): 1372-1378.

25. Pioli PA, Amiel E, Schaefer TM, et al. Differential expression of Toll-like receptors 2 and 4 in tissues of the human female reproductive tract. Infect Immun. 2004;72(10):5799-5806.

26. Schaefer TM, Desouza K, Fahey JV, Beagley KW, Wira CR. Toll-like receptor (TLR) expression and TLR-mediated cytokine/chemokine production by human uterine epithelial cells. Immunology. 2004; 112(3):428-436

27. Schaefer TM, Fahey JV, Wright JA, Wira CR. Innate immunity in the human female reproductive tract: antiviral response of uterine epithelial cells to the TLR3 agonist poly(I:C).J Immunol. 2005;174(2): 992-1002.

28. Fahey JV, Wright JA, Shen L, et al. Estradiol selectively regulates innate immune function by polarized human uterine epithelial cells in culture. Mucosal Immunol. 2008;1(4):317-325.

29. King AE, Critchley HO, Kelly RW. Presence of secretory leukocyte protease inhibitor in human endometrium and first trimester decidua suggests an antibacterial protective role. Mol Hum Reprod. 2000;6(2): 191-196.

30. King AE, Fleming DC, Critchley HO, Kelly RW. Differential expression of the natural antimicrobials, beta-defensins 3 and 4, in human endometrium. J Reprod Immunol. 2003;59(1):1-16.

31. Quayle AJ, Porter EM, Nussbaum AA, et al. Gene expression, immunolocalization, and secretion of human defensin-5 in human female reproductive tract. Am J Pathol. 1998;152(5):1247-1258.

32. Valore EV, Park CH, Quayle AJ, et al. Human b-defensin-1, an antimicrobial peptide of urogenital tissues. J Clin Invest. 1998;101: $1633-1642$.

33. Crane-Godreau MA, Wira CR. Effects of estradiol on lipopolysaccharide and Pam3Cys stimulation of CCL20/macrophage inflammatory protein 3 alpha and tumor necrosis factor alpha production by uterine epithelial cells in culture. Infect Immun. 2005;73(7):4231-4237.

34. Ghosh M, Shen Z, Schaefer TM, et al. CCL20/MIP3alpha is a novel anti-HIV-1 molecule of the human female reproductive tract. Am J Reprod Immunol. 2009;62(1):60-71.

35. Cai R, Carpick B, Chun RF, Jeang KT, Williams BR. HIV-I TAT inhibits PKR activity by both RNA-dependent and RNA-independent mechanisms. Arch Biochem Biophys. 2000;373(2):361-367.

36. Gatignol A, Laine S, Clerzius G. Dual role of TRBP in HIV replication and RNA interference: viral diversion of a cellular pathway or evasion from antiviral immunity? Retrovirology. 2005;2:65.

37. Malmgaard L. Induction and regulation of IFNs during viral infections. J Interferon Cytokine Res. 2004;24(8):439-454.

38. Sen GC, Peters GA. Viral stress-inducible genes. Adv Virus Res. 2007; 70:233-263.

39. Sen GC, Sarkar SN. The interferon-stimulated genes: targets of direct signaling by interferons, double-stranded RNA, and viruses. Curr Top Microbiol Immunol. 2007;316:233-250.

40. Marsili G, Borsetti A, Sgarbanti M, et al. On the role of interferon regulatory factors in HIV-1 replication. Ann NY Acad Sci. 2003;1010: $29-42$.

41. Givan AL, White HD, Stern JE, et al. Flow cytometric analysis of leukocytes in the human female reproductive tract: comparison of fallopian tube, uterus, cervix, and vagina. Am J Reprod Immunol. 1997;38(5):350-359. 
42. Eriksson M, Meadows SK, Wira CR, Sentman CL. Unique phenotype of human uterine NK cells and their regulation by endogenous TGF-beta. J Leukoc Biol. 2004;76(3):667-675.

43. Smith JM, Wira CR, Fanger MW, Shen L. Human fallopian tube neutrophils: a distinct phenotype from blood neutrophils. Am J Reprod Immunol. 2006;56:218-229.

44. Ochiel DO, Ghosh M, Fahey JV, Guyre PM, Wira CR. Human uterine epithelial cell secretions regulate dendritic cell differentiation and responses to TLR ligands. J Leukoc Biol. In press 2010.

45. Pioli PA, Weaver LK, Schaefer TM, et al. Lipopolysaccharide-induced IL-1 beta production by human uterine macrophages up-regulates uterine epithelial cell expression of human beta-defensin 2. J Immunol. 2006;176(11):6647-6655.

46. Sentman CL, Wira CR, Eriksson M. NK cell function in the human female reproductive tract. Am J Reprod Immunol. 2007;57(2):108-115.

47. Mselle TF, Meadows SK, Eriksson M, et al. Unique characteristics of NK cells throughout the human female reproductive tract. Clin Immunol. 2007;124(1):69-76.

48. Choudhury SR, Knapp LA. Human reproductive failure II: immunogenetic and interacting factors. Hum Reprod Update. 2001;7(2): $135-160$.

49. Kopcow HD, Eriksson M, Mselle TF, et al. Human decidual NK cells from gravid uteri and NK cells from cycling endometrium are distinct NK cell subsets. Placenta. In press 2010.

50. Yao V, Platell C, Hall JC. Dendritic cells. ANZ J Surg. 2002;72(7): 501-506.

51. Gupta P, Collins KB, Ratner D, et al. Memory CD4(+) T cells are the earliest detectable human immunodeficiency virus type 1 (HIV-1)infected cells in the female genital mucosal tissue during HIV-1 transmission in an organ culture system. J Virol. 2002;76(19):9868-9876.

52. Mestecky J, Moldoveanu Z, Smith PD, Hel Z, Alexander RC. Mucosal immunology of the genital and gastrointestinal tracts and HIV-1 infection. J Reprod Immunol. 2009;83(1-2):196-200.

53. Moldoveanu Z, Mestecky J. Mucosal antibody responses to HIV. Methods Mol Biol. 2009;485:333-345.

54. Keller M, Guzman E, Hazrati E, et al. PRO 2000 elicits a decline in genital tract immune mediators without compromising intrinsic antimicrobial activity. AIDS. 2007;21:467-476.

55. Bingle CD, Vyakarnam A. Novel innate immune functions of the whey acidic protein family. Trends Immunol. 2008;29(9):444-453.

56. Cole AM, Cole AL. Antimicrobial polypeptides are key anti-HIV-1 effector molecules of cervicovaginal host defense. Am J Reprod Immunol. 2008;59(1):27-34.

57. Iqbal SM, Kaul R. Mucosal innate immunity as a determinant of HIV susceptibility. Am J Reprod Immunol. 2008;59(1):44-54.

58. Ma G, Greenwell-Wild T, Lei K, et al. Secretory leukocyte protease inhibitor binds to annexin II, a cofactor for macrophage HIV-1 infection. J Exp Med. 2004;200(10):1337-1346.

59. Py B, Basmaciogullari S, Bouchet J, et al. The phospholipid scramblases 1 and 4 are cellular receptors for the secretory leukocyte protease inhibitor and interact with CD4 at the plasma membrane. PLoS One. 2009;4(3):e5006.

60. Weinberg A, Quinones-Mateu ME, Lederman MM. Role of human beta-defensins in HIV infection. Adv Dent Res. 2006;19(1):42-48.

61. Seidel A, Ye Y, de Armas LR, et al. Cyclic and acyclic defensins inhibit human immunodeficiency virus type-1 replication by different mechanisms. PLoS One. 2010;5(3):e9737.

62. Furci L, Sironi F, Tolazzi M, Vassena L, Lusso P. Alpha-defensins block the early steps of HIV-1 infection: interference with the binding of gp120 to CD4. Blood. 2007;109(7):2928-2935.

63. Skott P, Lucht E, Ehnlund M, Bjorling E. Inhibitory function of secretory leukocyte proteinase inhibitor (SLPI) in human saliva is HIV-1 specific and varies with virus tropism. Oral Dis. 2002;8(3):160-167.

64. Ishikawa $\mathrm{C}$, Tanabe $\mathrm{H}$, Maemoto A, et al. Precursor processing of human defensin-5 is essential to the multiple functions in vitro and in vivo. J Innate Immun. 2010;2:66-76.
65. Guyot N, Zani ML, Berger P, Dallet-Choisy S, Moreau T. Proteolytic susceptibility of the serine protease inhibitor trappin-2 (pre-elafin): evidence for tryptase-mediated generation of elafin. Biol Chem. 2005; 386(4):391-399.

66. Jokimaa V, Oksjoki S, Kujari H, Vuorio E, Anttila L. Expression patterns of cathepsins B, H, K, L and S in the human endometrium. Mol Hum Reprod. 2001;7(1):73-78.

67. McQuibban GA, Gong JH, Tam EM, et al. Inflammation dampened by gelatinase A cleavage of monocyte chemoattractant protein-3. Science. 2000;289(5482):1202-1206.

68. Wilson CL, Ouellette AJ, Satchell DP, et al. Regulation of intestinal alpha-defensin activation by the metalloproteinase matrilysin in innate host defense. Science. 1999;286(5437):113-117.

69. Zhang K, McQuibban GA, Silva C, et al. HIV-induced metalloproteinase processing of the chemokine stromal cell derived factor-1 causes neurodegeneration. Nat Neurosci. 2003;6(10):1064-1071.

70. Hasan L, Mazzucchelli L, Liebi M, et al. Function of liver activationregulated chemokine/CC chemokine ligand 20 is differently affected by cathepsin B and cathepsin D processing. J Immunol. 2006;176(11): $6512-6522$.

71. Taggart CC, Greene CM, Smith SG, et al. Inactivation of human betadefensins 2 and 3 by elastolytic cathepsins. J Immunol. 2003;171(2): 931-937.

72. Lim JK, Lu W, Hartley O, DeVico AL. N-terminal proteolytic processing by cathepsin G converts RANTES/CCL5 and related analogs into a truncated 4-68 variant. J Leukoc Biol. 2006;80(6):1395-1404.

73. Cummins JE, Christensen L, Lennox JL, et al. Mucosal innate immune factors in the female genital tract are associated with vaginal HIV-1 shedding independent of plasma viral load. AIDS Res Hum Retroviruses. 2006;22(8):788-795.

74. El Messaoudi K, Thiry L, Van Tieghem N, et al. HIV-1 infectivity and host range modification by cathepsin $\mathrm{D}$ present in human vaginal secretions. AIDS. 1999;13(3):333-339.

75. El Messaoudi K, Thiry LF, Liesnard C, et al. A human milk factor susceptible to cathepsin D inhibitors enhances human immunodeficiency virus type 1 infectivity and allows virus entry into a mammary epithelial cell line. J Virol. 2000;74(2):1004-1007.

76. Shaw JL, Diamandis EP. Regulation of human tissue kallikrein-related peptidase expression by steroid hormones in 32 cell lines. Biol Chem. 2008;389(11):1409-1419.

77. Shaw JL, Petraki C, Watson C, Bocking A, Diamandis EP. Role of tissue kallikrein-related peptidases in cervical mucus remodeling and host defense. Biol Chem. 2008;389(12):1513-1522.

78. Steinstraesser L, Tippler B, Mertens J, et al. Inhibition of early steps in the lentiviral replication cycle by cathelicidin host defense peptides. Retrovirology. 2005;2:2.

79. Yamasaki K, Schauber J, Coda A, et al. Kallikrein-mediated proteolysis regulates the antimicrobial effects of cathelicidins in skin. FASEB J. 2006;20(12):2068-2080.

80. Oravecz T, Pall M, Roderiquez G, et al. Regulation of the receptor specificity and function of the chemokine RANTES (regulated on activation, normal $\mathrm{T}$ cell expressed and secreted) by dipeptidyl peptidase IV (CD26)-mediated cleavage. J Exp Med. 1997;186(11): 1865-1872.

81. Shioda T, Kato H, Ohnishi Y, et al. Anti-HIV-1 and chemotactic activities of human stromal cell-derived factor 1alpha (SDF-1alpha) and SDF-1beta are abolished by CD26/dipeptidyl peptidase IV-mediated cleavage. Proc Natl Acad Sci U S A. 1998;95(11):6331-6336.

82. Ansari AW, Heiken H, Moenkemeyer M, Schmidt RE. Dichotomous effects of C-C chemokines in HIV-1 pathogenesis. Immunol Lett. 2007; $110(1): 1-5$.

83. Garzino-Demo A. Chemokines and defensins as HIV suppressive factors: an evolving story. Curr Pharm Des. 2007;13(2):163-172.

84. Ghosh M, Shen Z, Fahey JV, et al. Trappin-2/Elafin: a novel innate anti-HIV-1 molecule of the human female reproductive tract. Immunology. In press 2009. 
85. Iqbal SM, Ball TB, Levinson P, et al. Elevated elafin/trappin-2 in the female genital tract is associated with protection against HIV acquisition. AIDS. 2009;23(13):1669-1677.

86. Moreau T, Baranger K, Dade S, et al. Multifaceted roles of human elafin and secretory leukocyte proteinase inhibitor (SLPI), two serine protease inhibitors of the chelonianin family. Biochimie. 2008;90(2): 284-295.

87. Asin SN, Heimberg AM, Eszterhas SK, Rollenhagen C, Howell AL. Estradiol and progesterone regulate HIV type 1 replication in peripheral blood cells. AIDS Res Hum Retroviruses. 2008;24(5):701-716.

88. Katagiri D, Hayashi H, Victoriano AF, Okamoto T, Onozaki K. Estrogen stimulates transcription of human immunodeficiency virus type 1 (HIV-1). Int Immunopharmacol. 2006;6(2):170-181.

89. Lavreys L, Baeten JM, Kreiss JK, et al. Injectable contraceptive use and genital ulcer disease during the early phase of HIV-1 infection increase plasma virus load in women. J Infect Dis. 2004;189(2):303-311.

90. Lavreys L, Baeten JM, Martin HL Jr, et al. Hormonal contraception and risk of HIV-1 acquisition: results of a 10-year prospective study. AIDS. 2004;18(4):695-697.

91. Plummer FA, Simonsen JN, Cameron DW, et al. Cofactors in malefemale sexual transmission of human immunodeficiency virus type 1 . J Infect Dis. 1991;163(2):233-239.

92. Hel Z, Stringer E, Mestecky J. Sex steroid hormones, hormonal contraception, and the immunobiology of human immunodeficiency virus-1 infection. Endocr Rev. 2010;31(1):79-97.

93. Kiddugavu M, Makumbi F, Wawer MJ, et al. Hormonal contraceptive use and HIV-1 infection in a population-based cohort in Rakai, Uganda. AIDS. 2003;17(2):233-240.

94. Miller L, Patton DL, Meier A, et al. Depomedroxyprogesteroneinduced hypoestrogenism and changes in vaginal flora and epithelium. Obstet Gynecol. 2000;96(3):431-439.

95. Smith CL, Wolford RG, O’Neill TB, Hager GL. Characterization of transiently and constitutively expressed progesterone receptors: evidence for two functional states. Mol Endocrinol. 2000;14(7): 956-971.

96. Sheffield JS, Wendel GD Jr, McIntire DD, Norgard MV. The effect of progesterone levels and pregnancy on HIV-1 coreceptor expression. Reprod Sci. 2009;16(1):20-31.

97. de Jong MA, de Witte L, Oudhoff MJ, et al. TNF-alpha and TLR agonists increase susceptibility to HIV-1 transmission by human Langerhans cells ex vivo. J Clin Invest. 2008;118(10):3440-3452.

98. Spear GT, al-Harthi L, Sha B, et al. A potent activator of HIV-1 replication is present in the genital tract of a subset of HIV-1-infected and uninfected women. AIDS. 1997;11(11):1319-1326.

99. Spear GT, Zariffard MR, Chen HY, et al. Positive association between HIV RNA and IL-6 in the genital tract of Rwandan women. AIDS Res Hum Retroviruses. 2008;24(7):973-976.

100. Stoddard E, Ni H, Cannon G, et al. gp340 promotes transcytosis of human immunodeficiency virus type 1 in genital tract-derived cell lines and primary endocervical tissue. J Virol. 2009;83(17):8596-8603.
101. Hart CE, Lennox JL, Pratt-Palmore M, et al. Correlation of human immunodeficiency virus type 1 RNA levels in blood and the female genital tract. J Infect Dis. 1999;179(4):871-882.

102. Uvin SC, Caliendo AM. Cervicovaginal human immunodeficiency virus secretion and plasma viral load in human immunodeficiency virus-seropositive women. Obstet Gynecol. 1997;90(5):739-743.

103. Saracino A, Di Stefano M, Fiore JR, et al. Frequent detection of HIV-1 RNA but low rates of HIV-1 isolation in cervicovaginal secretions from infected women. New Microbiol. 2000;23(1):79-83.

104. Coombs RW, Wright DJ, Reichelderfer PS, et al. Variation of human immunodeficiency virus type 1 viral RNA levels in the female genital tract: implications for applying measurements to individual women. J Infect Dis. 2001;184(9):1187-1191.

105. Coleman JS, Hitti J, Bukusi EA, et al. Infectious correlates of HIV-1 shedding in the female upper and lower genital tracts. AIDS. 2007;21(6):755-759.

106. Spear GT, St John E, Zariffard MR. Bacterial vaginosis and human immunodeficiency virus infection. AIDS Res Ther. 2007;4:25.

107. St John E, Mares D, Spear GT. Bacterial vaginosis and host immunity. Curr HIV/AIDS Rep. 2007;4(1):22-28.

108. Chun TW, Engel D, Mizell SB, Ehler LA, Fauci AS. Induction of HIV-1 replication in latently infected CD4+ T cells using a combination of cytokines. J Exp Med. 1998;188(1):83-91.

109. Poli G, Bressler P, Kinter A, et al. Interleukin 6 induces human immunodeficiency virus expression in infected monocytic cells alone and in synergy with tumor necrosis factor alpha by transcriptional and post-transcriptional mechanisms. J Exp Med. 1990;172(1):151-158.

110. Poli G, Kinter A, Justement JS, et al. Tumor necrosis factor alpha functions in an autocrine manner in the induction of human immunodeficiency virus expression. Proc Natl Acad Sci U S A. 1990;87(2):782-785.

111. Poli G, Kinter AL, Fauci AS. Interleukin 1 induces expression of the human immunodeficiency virus alone and in synergy with interleukin 6 in chronically infected U1 cells: inhibition of inductive effects by the interleukin 1 receptor antagonist. Proc Natl Acad Sci USA. 1994;91(1):108-112.

112. Hashemi FB, Mollenhauer J, Madsen LD, et al. Myeloid-related protein (MRP)-8 from cervico-vaginal secretions activates HIV replication. AIDS. 2001;15(4):441-449.

113. Levinson P, Kaul R, Kimani J, et al. Levels of innate immune factors in genital fluids: association of alpha defensins and LL-37 with genital infections and increased HIV acquisition. AIDS. 2009;23(3): 309-317.

114. Bretschneider N, Kangaspeska S, Seifert M, et al. E2-mediated cathepsin D (CTSD) activation involves looping of distal enhancer elements. Mol Oncol. 2008;2(2):182-190.

115. Venkataraman N, Cole AL, Svoboda P, Pohl J, Cole AM. Cationic polypeptides are required for anti-HIV-1 activity of human vaginal fluid. J Immunol. 2005;175(11):7560-7567.
Virus Adaptation and Treatment

\section{Publish your work in this journal}

Virus Adaptation and Treatment is an international, peer-reviewed open access journal focusing on the study of virology, viral adaptation and the development and use of antiviral drugs and vaccines to achieve improved outcomes in infection control and treatment. The journa welcomes original research, basic science, clinical \& epidemiological

\section{Dovepress}

studies, reviews \& evaluations, expert opinion and commentary, case reports and extended reports. The manuscript management system is completely online and includes a very quick and fair peer-review system, which is all easy to use. Visit http://www.dovepress.com/ testimonials.php to read real quotes from published authors. 